\title{
Pengaruh Acetobacter xylinum dan Ekstrak Kacang Hijau (Phaseolus radiatus L.) terhadap Produksi Nata dari Substrat Limbah Cair Tahu
}

\section{Effect of Acetobacter xylinum and Green-bean Phaseolus radiatus L. on the Nata Production from Tofu Waste-water}

\author{
George M. Souisa, B.R. Sidharta*, F. Sinung Pranata \\ Fakultas Biologi, Universitas Atma Jaya Yogyakarta (UAJY) \\ e-mail: brsidharta@mail.uajy.ac.id *penulis untuk korespondensi
}

\begin{abstract}
Industrial waste-water has become a serious problem nationwide. However, one type of waste-water, i.e. tofu waste-water (whey), can be utilized as the source of nata de soya production. This present research is attempts to reveal the effect of various concentrations of inocula and green-bean extracts on nata productions from tofu wastewater. Ten combinations of treatment were applied and coded as $A_{1}-A_{10}$. The parameters observed included physical and chemical characters of nata and nitrogen (N) contents. The results show that the increase in concentration of $\mathrm{N}$ and inocula will follow by the increase of water content, fiber content, plasticity, and $N$ content of nata de soya produced. Highest thickness of nata was gained at $200 \mathrm{~g} / \mathrm{L}$ concentration of green-bean extract and $100 \mathrm{ml} / \mathrm{L}$ concentration of inoculum.
\end{abstract}

Key words : nata de soya, $\mathrm{N}$-natural source, tofu waste-water

Diterima : 04 Agustus 2005, disetujui : 17 Desember 2005

\section{Pendahuluan}

Penanganan air limbah industri maupun limbah rumah tangga semakin menarik untuk dipelajari. Pengolahan air limbah, selain menghasilkan air buangan yang bersih juga dapat dimanfaatkan lebih lanjut sebagai produk olahan yang dapat memberikan nilai tambah yang cukup tinggi.

Salah satu air limbah yang dapat memberikan nilai tambah yang tinggi adalah limbah cair tahu atau air kecutan (whey). Air kecutan (whey) merupakan limbah cair pabrik pengolahan tahu terutama berasal dari air rendaman kedelai, air tirisan kedelai setelah perendaman, air hasil pemisahan tahu dan air yang keluar saat pengepresan berlangsung (Hastuti dan Raharjo, 1983).

Air kecutan ternyata masih kaya akan nutrien (protein, karbohidrat, dan bahan-bahan lain) yang bermanfaat dan dapat diolah menjadi suatu produk yang bernilai, seperti keripik tahu dan nata de soya. Pada tahun 1990 ditemukan cara pemanfaatan limbah tahu menjadi nata de soya yang bila dilakukan secara nasional, dapat mengurangi limbah yang mengganggu lingkungan sekitar pabrik. Namun sampai sekarang nata de soya belum banyak diusahakan secara ekonomis (Anonim, 1997).

Nata adalah produk pangan berupa lapisan selulosa sebagai hasil fermentasi bakteri pembentuk nata, yaitu Acetobacter xylinum. Nata merupakan makanan berkalori rendah yang sebagian besar tersusun dari air dan selulosa sehingga sering digunakan sebagai makanan pencuci mulut, bahan pencampur fruit cocktail, dan es krim (Girsang dan Siahaan, 1992).

Sudah banyak penelitian yang dilakukan untuk menghasilkan nata dengan kualitas dan kuantitas yang lebih baik. Penelitian tersebut dilakukan dengan mengkaji faktor-faktor pendukung pembentukan nata, di antaranya 
adalah sumber nitrogen (N) dan kadar inokulum. Namun banyak penelitian yang menggunakan sumber $\mathrm{N}$ dari pupuk anorganik seperti urea atau ZA. Beberapa contoh penelitian yang menggunakan sumber $\mathrm{N}$ anorganik antara lain penelitian oleh Muchtadi (1997) dalam pembuatan nata de pin̆a serta penelitian oleh Lestari (1994) dalam pembuatan nata menggunakan urea.

Sumber $\mathrm{N}$ alami dari tumbuhan terutama Familia Papilionaceae dapat digunakan sebagai pengganti sumber $\mathrm{N}$ anorganik dalam pembuatan nata de soya. Kacang hijau (Phaseolus radiatus L.) memiliki kandungan gizi yang lengkap dibandingkan kedelai dan kacang tanah (Rukmana, 1997). Kandungan vitamin dalam kacang hijau lebih baik daripada kedelai dan kacang tanah. Selain itu, kacang hijau memiliki kandungan lemak yang rendah, sehingga dapat dimanfaatkan untuk mencegah penyakit antara lain hepatitis (Rukmana, 1997).

Penelitian ini bertujuan untuk mengetahui pengaruh kadar inokulum Acetobacter xylinum dan penambahan ekstrak biji kacang hijau (Phaseolus radiatus L.) terhadap kualitas dan kuantitas nata de soya dari medium air kecutan (whey).

\section{Metode Penelitian}

Pembuatan nata de soya menggunakan bantuan Acetobacter xylinum dengan variasi kadar inokulum yaitu 50, 100, dan $150 \mathrm{ml} /$ liter. Pengamatan dilakukan terhadap parameter fisik nata: ketebalan dan kekenyalan (Nugerahani et al., 1999), parameter kimia nata: kadar air, kadar serat, dan kadar N (Sudarmadji et al., 1989), serta uji organoleptik: warna, rasa, dan aroma (Kartika dan Bambang, 1986).

Ekstraksi kacang hijau dilakukan dengan cara merendam kacang hijau $(100,200$, dan 300 g) selama 10 jam, kemudian direbus hingga mendidih. Air rebusan kacang hijau digunakan sebagai sumber $\mathrm{N}$ alami.

Tahapan pembuatan nata adalah sebagai berikut: whey diendapkan (didiamkan), kemudian disaring dengan kain kassa, lalu dipanaskan sampai mendidih sambil diaduk. Setelah mendidih ditambah asam asetat glasial $(10 \mathrm{ml}$ asam asetat untuk tiap liter whey) sampai $\mathrm{pH} 4$ dan gula pasir (80 gram gula untuk tiap liter whey). Larutan itu disebut sebagai whey asam bergula. Ekstrak kacang hijau dilarutkan dalam whey asam bergula (masing-masing 0, 100, 200 dan 300 gram ekstrak kacang hijau dalam $100 \mathrm{ml}$ whey). Larutan ini dididihkan 15 menit, kemudian dimasukkan ke dalam whey asam bergula. Larutan yang diperoleh disebut medium nata. Selanjutnya medium nata dimasukkan ke dalam wadah-wadah fermentasi yang sudah disterilkan. Wadah ditutup dengan kertas bersih yang telah di-oven pada suhu $95-100^{\circ} \mathrm{C}$ selama 2 jam dan diikat karet. Setelah dingin, medium nata ditambah starter (tiap 1 liter medium ditambahkan masing-masing 10, 20, dan $30 \mathrm{ml}$ starter). Wadah berisi medium dan starter disimpan di ruang fermentasi selama 1015 hari sampai terbentuk lapisan nata dengan ketebalan 1,5-2,0 cm (Anonim, 1998).

Data dianalisis dengan metode ANAVA dan Duncan's Multiple Range Test (DMRT) pada taraf kepercayaan 95\% (Gaspersz, 1991).

\section{Hasil dan Pembahasan}

Nata de soya yang dihasilkan memiliki permukaan yang mengkilat dan berwarna putih sampai putih keruh. Warna keruh tersebut mungkin dipengaruhi oleh sumber $\mathrm{N}$ dari kacang hijau dan whey yang digunakan (Gambar 1).

Nata de soya merupakan polisakarida yang diekskresikan ke medium dalam bentuk benang-benang halus yang membentuk lapisan micoderma (struktur serupa selimut yang menyelubungi sel), selanjutnya membentuk jalinan mikrofibril dalam medium whey. Hasil respirasi bakteri berupa $\mathrm{CO}_{2}$ (gas) yang melekat pada jaringan mikrofibril menyebabkan nata terangkat ke permukaan medium. 


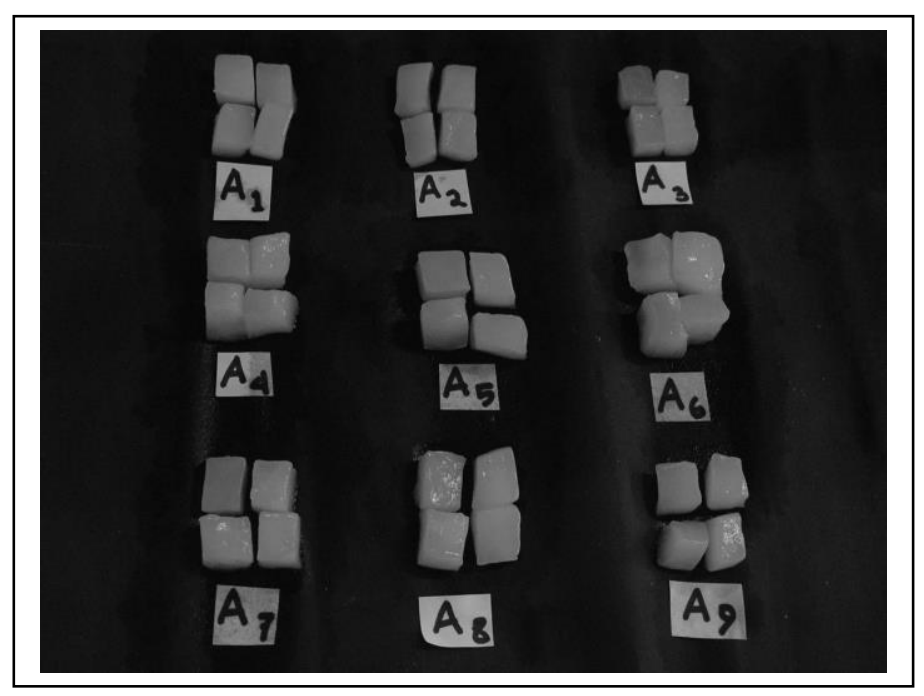

Gambar 1. Nata de soya dari berbagai variasi konsentrasi sumber $\mathrm{N}$ dan Inokulum Keterangan:

$\mathrm{A}_{1}$ : starter $50 \mathrm{ml}$, kacang hijau $100 \mathrm{ml}$ $\mathrm{A}_{3}$ : starter $50 \mathrm{ml}$, kacang hijau $300 \mathrm{ml}$ $\mathrm{A}_{5}$ : starter $100 \mathrm{ml}$, kacang hijau $200 \mathrm{ml}$ $\mathrm{A}_{7}$ : starter $150 \mathrm{ml}$, kacang hijau $100 \mathrm{ml}$ $\mathrm{A}_{9}$ : starter $150 \mathrm{ml}$, kacang hijau $300 \mathrm{ml}$
$\mathrm{A}_{2}$ : starter $50 \mathrm{ml}$, kacang hijau $200 \mathrm{ml}$ $\mathrm{A}_{4}$ : starter $100 \mathrm{ml}$, kacang hijau $100 \mathrm{ml}$ $\mathrm{A}_{6}$ : starter $100 \mathrm{ml}$, kacang hijau $300 \mathrm{ml}$ $\mathrm{A}_{8}$ : starter $150 \mathrm{ml}$, kacang hijau $200 \mathrm{ml}$

\section{Kualitas serta Kuantitas Nata yang Dihasilkan}

Pada Tabel 1 dapat dilihat pengaruh penambahan kacang hijau sebagai sumber $\mathrm{N}$ terhadap kualitas dan kuantitas nata de soya yang dihasilkan. Kualitas nata yang dihasilkan cukup baik dibandingkan penelitian yang menggunakan air kelapa, terutama ketebalannya, yaitu $0,83 \mathrm{~cm}$ untuk nata de soya dan hanya 0,48 untuk nata de coco (Parera, 2003). Hal ini disebabkan whey sudah mengandung $\mathrm{N}$ yang cukup tinggi yang masih ditambah lagi sumber $\mathrm{N}$ dari kacang hijau.

Tabel 1. Kualitas dan Kuantitas Nata de Soya Dari Berbagai Kadar N dan Inokulum

\begin{tabular}{|c|c|c|c|c|c|c|}
\hline Perlakuan & $\begin{array}{c}\text { Kadar Air } \\
(\%)\end{array}$ & $\begin{array}{c}\text { Kadar Serat } \\
(\%)\end{array}$ & $\begin{array}{c}\text { Kekenyalan } \\
\text { (mm division) }\end{array}$ & $\begin{array}{c}\text { Ketebalan } \\
(\mathrm{cm})\end{array}$ & $\begin{array}{c}\text { N sebelum } \\
(\mathrm{mg} / \mathrm{ml})\end{array}$ & $\begin{array}{c}\text { N sesudah } \\
(\mathrm{mg} / \mathrm{ml})\end{array}$ \\
\hline $\mathbf{A}_{1}$ & $92,23^{\mathrm{a}}$ & $0,45^{\mathrm{b}}$ & $6,71^{\mathrm{d}}$ & $0,60^{\mathrm{e}}$ & $10,17^{\mathrm{f}}$ & $14,83^{\mathrm{k}}$ \\
\hline $\mathbf{A}_{2}$ & $93,45^{\mathrm{a}}$ & $0,48^{\mathrm{b}}$ & $6,72^{d}$ & $0,67^{\mathrm{e}}$ & $10,43^{\mathrm{g}}$ & $14,85^{\mathrm{k}}$ \\
\hline $\mathbf{A}_{3}$ & $93,66^{\mathrm{a}}$ & $0,49^{b}$ & $6,78^{d}$ & $0,52^{\mathrm{e}}$ & $10,51^{\mathrm{h}}$ & $15,19^{\mathrm{k}}$ \\
\hline $\mathbf{A}_{4}$ & $93,26^{a}$ & $0,47^{\mathrm{b}}$ & $6,57^{d}$ & $0,70^{\mathrm{e}}$ & $10,47^{\mathrm{h}}$ & $14,94^{\mathrm{k}}$ \\
\hline A5 & $93,26^{\mathrm{a}}$ & $0,49^{\mathrm{b}}$ & $6,59^{d}$ & $0.75^{\mathrm{e}}$ & $10,73^{\mathrm{i}}$ & $15,13^{\mathrm{k}}$ \\
\hline $\mathbf{A}_{6}$ & $93,38^{a}$ & $0,54^{\mathrm{b}}$ & $6,70^{\mathrm{d}}$ & $0.83^{\mathrm{e}}$ & $10,87^{\mathrm{i}}$ & $15,27^{\mathrm{k}}$ \\
\hline $\mathbf{A}_{7}$ & $93,68^{a}$ & $0,43^{\mathrm{c}}$ & $8,22^{d}$ & $0.57^{\mathrm{e}}$ & $10,35^{\mathrm{g}}$ & $14,89^{\mathrm{k}}$ \\
\hline As & $93,94^{\mathrm{a}}$ & $0,44^{\mathrm{c}}$ & $8,31^{\mathrm{d}}$ & $0.62^{\mathrm{e}}$ & $10,75^{\mathrm{i}}$ & $14,91^{\mathrm{k}}$ \\
\hline A9 & $94,11^{\mathrm{a}}$ & $0,49^{b}$ & $8,42^{\mathrm{d}}$ & $0.53^{\mathrm{e}}$ & $11,03^{\mathrm{i}}$ & $15,46^{\mathrm{k}}$ \\
\hline A10 & --- & --- & --- & --- & $10,33^{j}$ & $15,35^{\mathrm{k}}$ \\
\hline
\end{tabular}

$\overline{\text { Keterangan : angka yang diikuti huruf yang sama dalam baris yang sama menunjukkan tidak beda nyata }(\alpha=0,05)}$

$\mathrm{A}_{1}-\mathrm{A}_{9} \quad$ : sama seperti keterangan pada Gambar 1

$\mathrm{A}_{10} \quad$ : kontrol (starter $0 \mathrm{ml}$, kacang hijau $0 \mathrm{ml}$ )

--- : tidak dilakukan pengukuran 


\section{Kadar Air}

Kadar air nata untuk tiap perlakuan dapat dilihat pada Gambar 2. Kadar air paling tinggi di antara perlakuan $\mathrm{N}$ yang sama dihasilkan pada $\mathrm{A}_{9}$, yaitu sebesar $94,11 \%$. Menurut Hubies et al. (1996), nata merupakan makanan berkalori rendah dengan kandungan air sebesar 98\%. Perlakuan ini tidak menunjukkan beda nyata secara statistik dengan perlakuan yang lain. Perlakuan $\mathrm{A}_{1}$, kandungan airnya yang paling kecil, yaitu 92,23\%. Perlakuan-perlakuan dengan kadar kacang hijau $300 \mathrm{~g} / \mathrm{L}$, memiliki kadar air yang cenderung lebih besar daripada perlakuan yang menggunakan kadar kacang hijau 100 g/L.

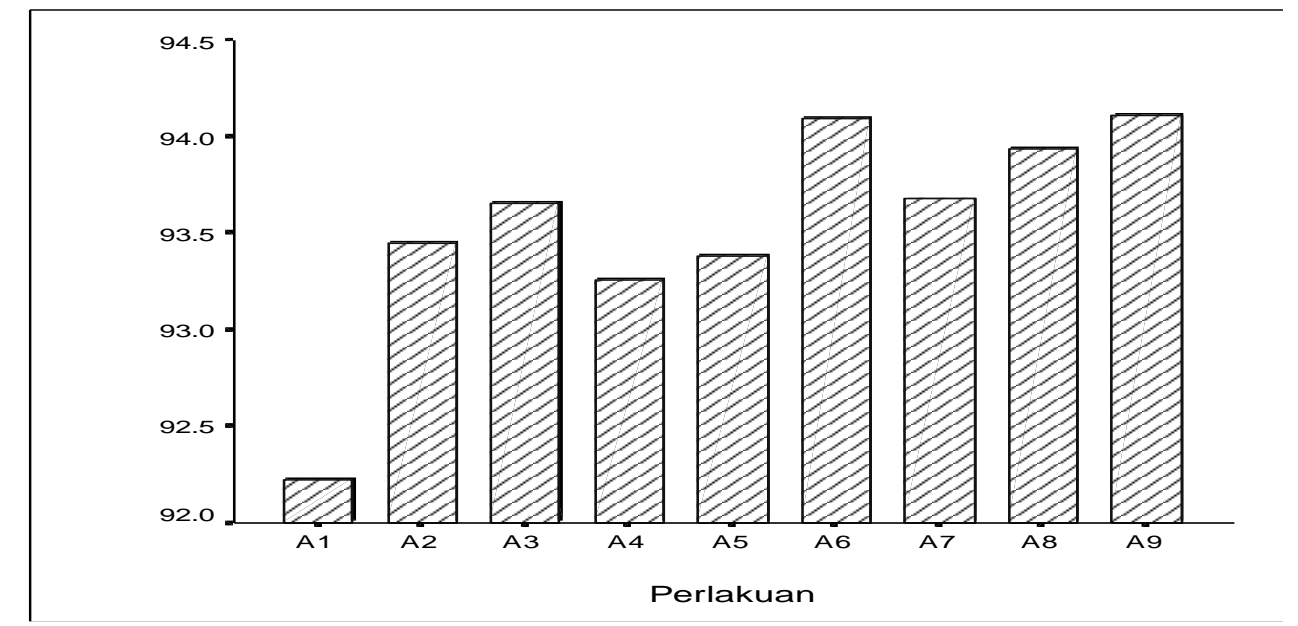

Gambar 2. Kadar Air Nata de Soya dengan Variasi Kadar Inokulum dan Nitrogen

Perbandingan kadar air yang tinggi cenderung terjadi pada perlakuan dengan sumber $\mathrm{N}$ kacang hijau terbesar. Hal ini disebabkan dalam kacang hijau terdapat lisin yaitu lemak yang dapat larut dalam air (Marzuki dan Rasyid, 2001). Kemungkinan lisin inilah yang mengikat air dalam nata sehingga menyebabkan kadar air dalam nata tinggi. Selain itu, air dalam nata mungkin berasal dari kacang hijau yaitu sebesar 10 g/100 g (Soeprapto, 2000) dan dari whey. Molekul air dalam medium akan terperangkap dalam nata melalui jaringan mikrofibril yang terbentuk oleh A. xylinum (Handayani, 1995).

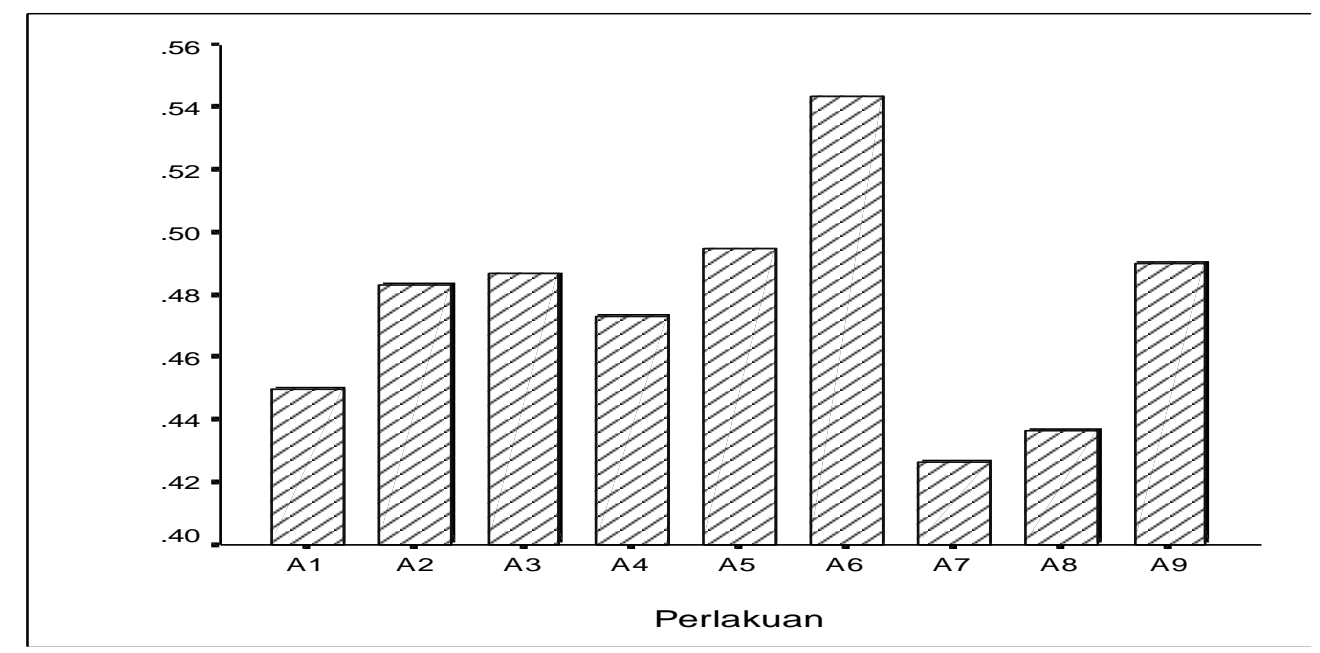

Gambar 3. Serat Kasar Nata de Soya dengan Variasi Kadar Inokulum dan Nitrogen 


\section{Kadar Serat}

Berdasarkan pengukuran kadar serat, menunjukkan bahwa kadar serat terbesar dijumpai pada perlakuan dengan konsentrasi kacang hijau sebagai sumber N $300 \mathrm{ml}$ dan kadar serat terkecil dijumpai pada perlakuan dengan kadar kacang hijau 100 dan 200 g/L (Tabel 1 dan Gambar 2). Besar kecilnya kadar serat dipengaruhi oleh kandungan $\mathrm{N}$ dalam medium. Semakin besar kadar N maka semakin besar pula kadar serat dalam nata. Nitrogen dalam medium akan dimanfaatkan oleh $A$. xylinum untuk pembentukkan sel-sel baru. Semakin banyak sel yang terbentuk akan memungkinkan pembentukan serat nata yang lebih banyak (Jutono et al., 1975).

\section{Kekenyalan}

Pengamatan kekenyalan pada nata (Tabel 1) diperoleh bahwa perlakuan dengan kadar kacang hijau $300 \mathrm{ml}$ cenderung lebih kenyal daripada perlakuan dengan kadar kacang hijau 100 dan $200 \mathrm{ml}$. Perlakuan A9 memiliki tingkat kekenyalan yang paling besar dibandingkan perlakuan lainnya, yaitu sebesar 8,42 mm. Menurut Hubies et al. (1996), perbandingan antara kadar serat dan kekenyalan adalah berbanding lurus, artinya semakin banyak kandungan serat maka semakin kenyal tekstur nata. Berdasarkan data yang diperoleh, kekenyalan dan serat kasar pada nata dengan perlakuan $\mathrm{A}_{1}-\mathrm{A}_{3}, \mathrm{~A}_{4}-\mathrm{A}_{6}$, dan $\mathrm{A}_{7}-\mathrm{A}_{9}$ mengalami peningkatan (Gambar 4).

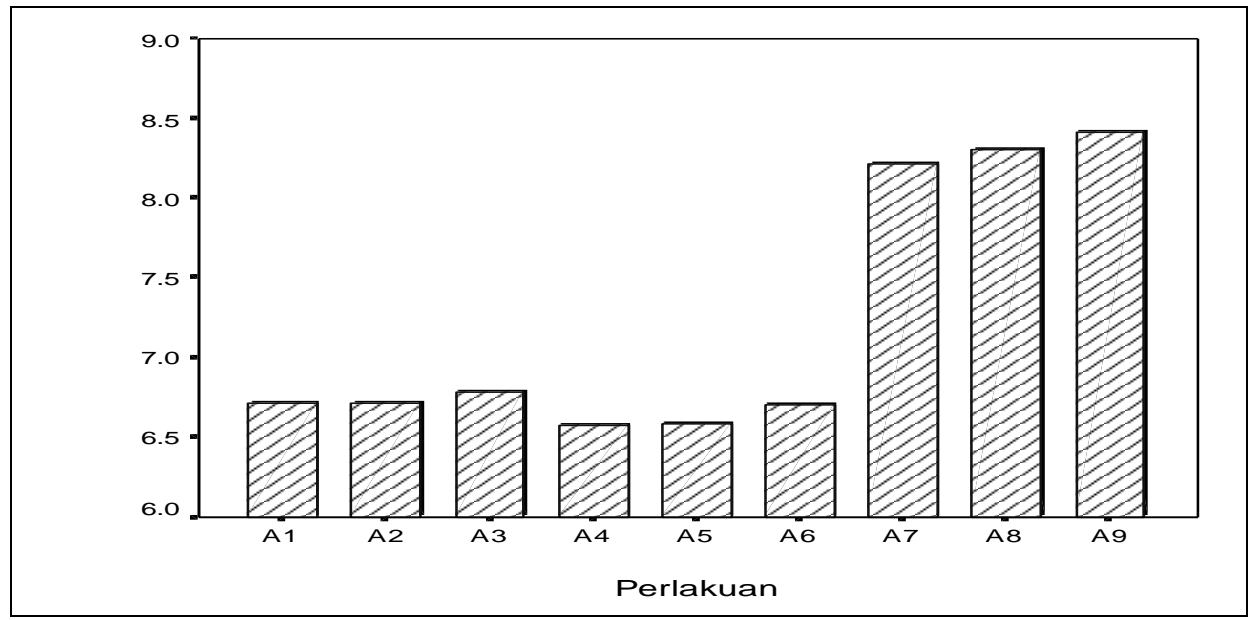

Gambar 4. Kekenyalan Nata de Soya dengan Variasi Kadar Inokulum dan Nitrogen

Berdasarkan hasil tersebut diketahui bahwa hubungan kekenyalan dan serat kasar tidak selalu berbanding lurus, walaupun kandungan $\mathrm{N}$ dalam medium lebih besar. Menurut Widia (1984), penurunan kekenyalan disebabkan terbentuknya ikatan antara unsur $\mathrm{N}$ dengan prekursor polisakarida yang mempunyai struktur polimer yang longgar, sehingga walaupun $\mathrm{N}$ dapat meningkatkan jumlah serat, tapi karena strukturnya longgar maka kekenyalan nata menjadi rendah.

\section{Ketebalan}

Ketebalan nata tertinggi terlihat pada medium whey dengan perlakuan $\mathrm{N}$ sebesar 200 $\mathrm{ml}\left(\mathrm{A}_{6}=0,83 \mathrm{~cm}\right)$, sedangkan ketebalan terendah ada pada perlakuan dengan kadar $\mathrm{N}$
$300 \mathrm{ml}\left(\mathrm{A}_{9}=0,53 \mathrm{~cm}\right)$. Namun, secara statistik ketebalan antarperlakuan tidak berbeda nyata $(\alpha=0,05)$.

Gambar 5 memperlihatkan perlakuan $\mathrm{A}_{3}$ dan $\mathrm{A}_{9}$ dengan ketebalan terendah di antara kelompok perlakuan yang sama. Hal ini disebabkan pada perlakuan $\mathrm{A}_{3}$ kadar inokulum yang ditambahkan sebesar $50 \mathrm{ml} / \mathrm{L}$ sedangkan kadar $\mathrm{N}$ yang diberikan $300 \mathrm{~g} / \mathrm{L}$ dan volume whey $1 \mathrm{~L}$. Bila ketersediaan nutrien dalam medium yang jumlah inokulumnya kecil terlalu banyak, maka nutrien tersebut justru dapat bersifat toksik terhadap mikrobia, sehingga produksi nata tidak maksimal. Menurut Kemal dan Tarwiyah (2001), volume starter yang ditambahkan harus sebanding dengan volume medium yang diberikan pada mikrobia. 


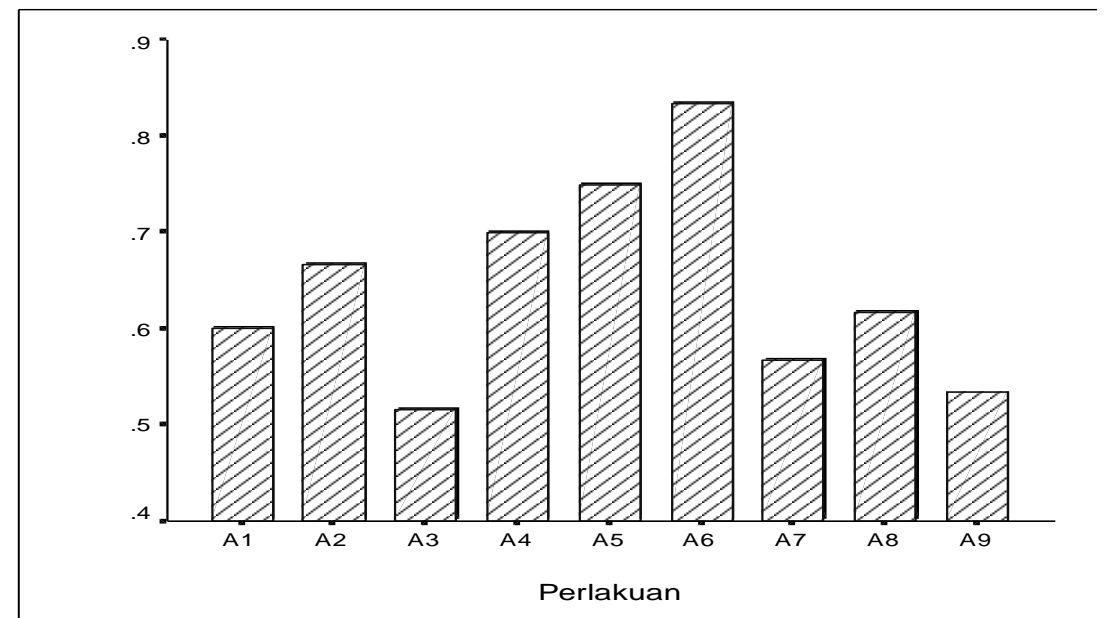

Gambar 5. Ketebalan Nata de Soya dengan Variasi Kadar Inokulum dan Nitrogen

Pada perlakuan $\mathrm{A}_{9}$ ketebalan nata juga menurun. Hal ini disebabkan pada perlakuan $\mathrm{A}_{9}$ kadar inokulum yang ditambahkan sebesar $150 \mathrm{ml}$ dan kadar $\mathrm{N}$ yang ditambahkan $300 \mathrm{ml}$ kacang hijau dengan volume whey $1 \mathrm{~L}$. Kadar inokulum yang terlalu banyak $(>10 \%)$ dan tidak diimbangi dengan ketersediaan nutrien yang cukup, akan menyebakan inokulum mengalami "kelaparan". Hal inilah yang menyebabkan produksi nata pada perlakuan $\mathrm{A}_{9}$ tidak optimal.

\section{Kandungan N dalam Medium Sebelum dan Sesudah Pembentukan Nata}

Nitrogen merupakan salah satu unsur yang sangat diperlukan dalam pertumbuhan $A$. xylinum. Ketersediaan dan jenis sumber $\mathrm{N}$ yang digunakan dalam substrat pertumbuhan $A$. xylinum sangat menentukan kualitas dan kuantitas nata yang dihasilkan. Berdasarkan pengamatan kandungan $\mathrm{N}$ dalam masingmasing perlakuan dengan hasil statistik berbeda nyata untuk kandungan $\mathrm{N}$ sebelum dikultur dan tidak berbeda nyata untuk kandungan $\mathrm{N}$ sesudah dikultur (Tabel 1). Kandungan $\mathrm{N}$ yang paling besar diperoleh pada perlakuan $\mathrm{A}_{9}$ yaitu 11,03 dan $15,46 \mathrm{mg} / \mathrm{ml}$ untuk sebelum dan sesudah kultur. Kandungan $\mathrm{N}$ paling rendah terjadi pada perlakuan $\mathrm{A}_{1}$ yaitu 10,17 dan 14,83 mg/ml untuk sebelum dan sesudah kultur.

Kandungan $\mathrm{N}$ pada perlakuan $\mathrm{A}_{9}$ cenderung tinggi karena kadar $\mathrm{N}$ yang ditambahkan cukup banyak yaitu $300 \mathrm{~g} / \mathrm{L}$ kacang hijau. Namun, perlakuan $\mathrm{A}_{9}$ kurang dapat menghasilkan nata secara maksimal bila dibandingkan dengan perlakuan A1 yang kandungan N-nya cenderung lebih rendah. Menurut Ekawaty (2004), kandungan N yang tinggi dalam medium pertumbuhan A. xylinum tidak selamanya dapat mengoptimalkan pertumbuhan bakteri tersebut. Kandungan $\mathrm{N}$ yang berlebih akan menghambat pertumbuhan bakteri dan akibatnya nata yang dihasilkan tidak maksimal.

Pengukuran kadar $\mathrm{N}$ sebelum dan sesudah pembentukkan nata de soya berfungsi untuk mengetahui apakah $\mathrm{N}$ tersedia dalam medium digunakan secara maksimal atau tidak. Berdasarkan hasil yang diperoleh, kandungan $\mathrm{N}$ sesudah pembentukan nata mengalami peningkatan. Peningkatan kadar $\mathrm{N}$ dalam medium saat pemanenan dimungkinkan karena masih terdapat $A$. xylinum saat dilakukan pengukuran. Dilaporkan pula bahwa 14\% dari berat sel adalah protein, yang juga banyak mengandung unsur N (Fardiaz, 1992; Tortora et al., 2001).

\section{Simpulan dan Saran}

Berdasarkan hasil pengamatan di atas, maka dapat ditarik simpulan: semakin tinggi kadar $\mathrm{N}$ dan inokulum yang ditambahkan dalam medium, maka semakin meningkat pula kadar air, kadar serat, kekenyalan, dan kandungan $\mathrm{N}$ dari nata yang dihasilkan. 
Penambahan $\mathrm{N}$ dapat menghasilkan tebal rerata nata yang paling tinggi pada kadar kacang hijau $200 \mathrm{~g} / \mathrm{L}$ dan pemberian inokulum yang menghasilkan rerata nata yang lebih tebal terjadi pada kadar inokulum $100 \mathrm{ml} / \mathrm{L}$.

Beberapa saran untuk penelitian selanjutnya, antara lain: Perlunya penelitian mengenai bahan dasar pembuatan nata de soya dan penggunaan sumber $\mathrm{N}$ alami selain kacang hijau, sehingga dapat menggantikan penggunaan $\mathrm{N}$ anorganik. Sentrifugasi medium setelah pemanenan nata perlu dilakukan sebelum mengukur $\mathrm{N}$ total untuk menghindari terukurnya kandungan $\mathrm{N}$ dari A. xylinum.

\section{Ucapan Terima Kasih}

Para peneliti mengucapkan terima kasih kepada pemilik Perusahaan Tahu " $X$ " di Klaten yang telah memberikan air kecutan (whey) sebagai medium pembuatan nata. Terima kasih juga disampaikan kepada Fakultas Biologi Universitas Atma Jaya Yogyakarta yang telah memberikan dukungan terhadap pelaksanaan penelitian ini.

\section{Daftar Pustaka}

Anonim. 1997. Nata Dibuat, Lingkungan Sehat, www.Indomedia.com/intisari/1997/mei/nataso ya.htm, 26 Juni 2002.

Anonim. 1998. Pengolahan Pangan Tentang Pembuatan Nata de Soya, www.ristek.go.id/ tentang pengolahan pangan/Nata de Soya, 16 Mei 2001.

Ekawaty, A. 2004. Kualitas dan Kuantitas Nata de Siwalan Pada Berbagai Kombinasi Sumber Nitrogen Ammonium Nitrat $\left(\mathrm{NH}_{4} \mathrm{NO}_{3}\right)$ dan Ekstrak Kacang Tanah (Arachis hypogaea L.), Skripsi, Fakultas Biologi, Universitas Atma Jaya Yogyakarta, Yogyakarta

Fardiaz, S. 1992. Mikrobiologi Pangan, PT. Gramedia Pustaka Utama, Jakarta, 213 hal.

Gaspersz, V. 1991. Metode Perancangan Percobaan, Armico, Bandung.

Girsang, P. dan Siahaan, D. 1992. Kelayakkan Usaha Nata de Coco Menggunakan Molina, Manggar. No 1 (15).

Handayani, D. 1995. Mempelajai Pengaruh Penggunaan Mill Juice Terhadap Laju Pertumbuhan dan Struktur Gel Nata de Coco di PP Great Giant Pineapple Company, Laporan Kerja Lapangan, UGM, Yogyakarta.
Hastuti, P. dan Raharjo, A.P. 1983. Pengolahan Hasil Tanaman Serealia dan Palawija, Direktorat Menengah Kejuruan Depdikbud, Jakarta.

Hubies, M.E., Arsatmojo dan Suliantri. 1996. Formulasi Pembuatan Nata de Pina, Buletin Teknologi dan Industri Pangan, 2 (4) : 32-39.

Jutono, Hartadi, S., Kabium, S., Susanto, Judoro dan Suhardi. 1975. Mikrobiologi Untuk Perguruan Tinggi, Fakultas Pertanian UGM, Yogyakarta.

Kartika dan Bambang. 1986. Uji Indrawi, Fakultas Teknologi Pertanian, UGM, Yogyakarta.

Kemal dan Tarwiyah. 2001. Nata de Cacao, Dewan IPTEK dan Indusrti, Padang, Sumatera Barat.

Lestari, R.S.E. 1994. Memasyarakatkan Model Usaha Industri Nata De soya dalam Rangka Perwujudan Pengembangan Agroindustri Akrab Lingkungan, Majalah Pangan. 20 (2) : 60-64.

Marzuki, R. dan Rasyid. 2001. Bertanam Kacang Hijau, Penebar Swadaya, Jakarta, hal. 11-24.

Muchtadi, T.R. 1997. Nata de Pina, Majalah Pangan. 33 (9) : 39-44.

Nugerahani, I., Epriliati, I., Kusumawati, N. dan Matoetina, M. 1999. Pengaruh Konsentrasi Inokulum Terhadap Sifat Fisikokimia Natta De Pinna, Jurnal Ilmiah Widya Mandala, Tahun VI. No. 001, Surabaya.

Parera, L.A.M. 2003. Pengaruh Variasi Sumber Nitrogen Alami dan pH Awal Medium Terhadap Kualitas Nata de Coco, Seminar Mahasiswa Fakultas Biologi Universitas Atma Jaya, Yogyakarta

Rukmana, R. 1997. Kacang Hijau, Penerbit Kanisius, Yogyakarta.

Soeprapto. 2000. Bertanam Kacang Hijau, Penebar Swadaya, Jakarta.

Sudarmadji, S.R., Kasmidjo, Sardjono, Wibowo, J., Margino, S. dan Endang, S.R. 1989. Mikrobiologi Pangan, PAU Pangan dan Gizi UGM, Yogyakarta.

Tortora, G.J., Funke, B.R. and Case, C.L. 2001. Microbiology an Introduction, Benjamin Cummings, an Imprint of Addison Wesley Longman, Inc, USA.

Widia, I.W. 1984. Mempelajari Pengaruh Penambahan Skim Milk Kelapa, Jenis Gula dan Mineral Dengan Berbagai Konsentrasi Pada Pembuatan Nata de Coco, Skripsi, jurusan Teknologi Pangan dan Gizi, IPB, Bogor. 